\title{
The Core Courses in the Manufacturing/Mechanical Engineering Technology Program
}

\author{
Bob Lahidji, Ph.D. \\ Eastern Michigan University
}

The competitive edge in manufacturing is no longer based upon the utilization of high tech equipment. The advantages associated with possessing high tech equipment has been diminished due to the availability and downward pricing of equipment. For example, in the automobile industry obtaining high tech equipment does not provide a competitive edge over the competitors. Today the emphasis is on continuous improvement, simplifying in manufacturing processes, and optimizing of human resources.

The objective of this paper is to report the core courses and laboratory activities in manufacturing/mechanical engineering technology programs. These programs prepare students for careers in America's changing industrial environment.

\section{Introduction}

Four-year Engineering Technology programs started in the early 1960's because engineering programs were becoming too theoretical. A baccalaureate in engineering technology prepares individuals to become engineering technologist. The Engineering Technology Council has defined engineering technology as a:

Profession in which a knowledge of the applied mathematical and natural sciences gained by higher education, experience, and practice is devoted to application of engineering principles and the implementation of technological advances for the benefit of humanity. Engineering technology education for the professional focuses primarily on analyzing, applying, implementing and improving existing technologies and is aimed at preparing graduates for the practice of engineering closest to the product improvement, manufacturing, and engineering operational functions. ${ }^{1}$

Today, there are about 110 colleges and universities which offer 315 ABET accredited programs in over 90 disciplines. ${ }^{2}$ The review of the literature reveals that the engineering technology curriculum is composed of 33\% mathematics and sciences, $25 \%$ liberal studies, and 40 to $45 \%$ in the major field of study. Approximately $67 \%$ of the course work in the major field of study in Engineering Technology subjects are involved in some type of laboratory activities. ${ }^{3}$ 


\section{Careers in Engineering Technology}

Graduates of engineering technology hold many different industrial positions with many of them being related to their undergraduate area of specialization. Some of the engineering technology graduates hold engineering jobs which have been assigned to them by industry. To show the theory and practice, refer to Figure $1 .^{4}$

\begin{tabular}{|l|c|c|c|c|c|}
\hline \multicolumn{5}{|c|}{ Pheory } & Practice \\
\hline \multicolumn{7}{|c|}{ Post 1940s } \\
\cline { 2 - 5 } & Scientist & Engineer & Technician & Craftsman & \\
\hline Scientist & Engineering & $\begin{array}{l}\text { Engineering } \\
\text { Technologist }\end{array}$ & $\begin{array}{c}\text { Industrial } \\
\text { Technologist }\end{array}$ & Industrial & Craftsman \\
\hline
\end{tabular}

Figure 1

\section{Accreditation}

The Technology Accreditation Commission (TAC) of the Accreditation Board for Engineering Technology (ABET) requires a minimum of 124 semester hour credits for the baccalaureate degree. In addition, the engineering technology curriculum must include the following components: ${ }^{5}$

I. The first component is the 48 semester hours of credit in the following areas:

Technical science: Subject matter in this area require the use of mathematics and basic science for the purpose of solving technical problems.

Technical specialties: Courses are those which provide students with the necessary skills and knowledge of appropriate methods, procedures, and techniques to adapt existing technical procedures to new situations and correctly complete given technical processes and procedures.

Technical electives: Any related technical courses that support the student's specialty.

II. Another curriculum component consists of 24 semester hours of basic sciences and mathematics.

Eight of the 24 hours must be in laboratory science.

Twelve of the 24 hours must be in mathematics. 
III. The third curriculum component is 24 semester hours of communications, humanities, and social science courses, with4minimum of nine hours in written and oral communications. According to ABET, "The remaining 28 semester hours or more should be designed for a well-rounded engineering technology graduate who can function successfully as an engineering technologist. The computer to solve technical problems along with a cooperative education experience for a maximum of eight semester hours is strongly recommended."

\section{Engineering Technology at Eastern Michigan University}

The Industrial Technology (IT) program at Eastern Michigan University has been recognized as one of the top five programs in the nation. In the past fifteen years, the IT program, with its five areas of study has served local industries and students. However, the industrial demand for graduates of ET programs was recognized by the College of Technology. Hence, the Department of Industrial Technology is developing two ET programs. (1) a bachelor of science degree program in mechanical engineering technology with concentrations in areas of manufacturing and design, (2) a bachelor of science degree program in electronic engineering technology.

The completion of 124 credit hours in the following six areas are required to receive a degree:

1. Symbol and communications 6

2. Science and technology 12

3. Social Science 12

4. Arts and humanities 11

5. Major requirements 71

6. Physical education activities 2

Total 124

Major Requirement Courses

The following courses represent the core courses for the manufacturing concentration

Materials I

Calculus II

Engineering Graphics

Manufacturing Processes I

Manufacturing Processes II

Industrial Electricity and Control I

Industrial Operation

Statistics

Industrial Electricity and Control II

CAD Application

Electricity and Light

Strength/Elasticity of Materials

Design for Manufacturing and Tooling

Engineering Dynamics 
Heat and Thermodynamics

Fluid Mechanics

Computer Numerical Control

Cooperative Education

Mechanical/Machine design

Industrial Quality Control

Manufacturing Engineering Analysis

Manufacturing Enterprise Capstone

\section{A typical course description}

The course Mechanical/Machine design was randomly selected from the above list to show a typical course description.

Course Number: $\quad$ CADM 411

Course Title: Mechanical/Machine Design

Credit Hours: 3

\section{Statement of Course Goals and Objectives:}

In this course the students will learn the fundamentals of mechanical design which include:

1. The meaning of mechanical design

2. The phases of design

3. Design consideration

4. Codes and standards

5. Stress analysis

6. Mohr's Circle

7. Failure criteria

8. Design for fatigue strength

9. Design of mechanical elements

(a) Screws and fasteners

(b) Welded joints

(c) Bearings

(d) Springs

(e) Gears.

\section{Course Description:}

A study of the decision-making processes which mechanical engineers use in the formulation of plans for the physical realization of machines, devices, and systems. Topics include the phases of design, codes and standards, stress analysis, failure criteria, design for fatigue strength, and the design of mechanical elements.

Prerequisites: $\quad$ MFG 123, COSC 137, CADM 21 1, PHY 229 


\section{Course Outline:}

1. Course overview

(a) Introduction to mechanical design

(b) Phases of design

2. Design consideration and design criteria

3. Stress and Mohr's Circle

4. Mohr's Circle and thermal stress

5. Euler columns and buckling

6. Materials and their properties

7. Failure criteria

8. Design for fatigue strength

9. Design of mechanical elements--screws and fasteners

10. Design of mechanical elements--welded joints

11. Design of mechanical elements-bearings

12. Design of mechanical elements-gears

\section{Recommended Text:}

Shigley, J.E., \& Mitchell, L.D. (1989). Mechanical engineering design. McGraw-Hill Book Company.

\section{Method of Course Evaluation:}

$\begin{array}{ll}2 \text { Exams } & 30 \%(15 \% \text { each }) \\ \text { Final exam } & 20 \% \\ \text { Quizzes } & 25 \% \\ \text { Assignments/Project } & 25 \%\end{array}$

\section{Laboratory Experience in ET Program}

According to Dr. Israel ${ }^{3}$, the laboratory experiences should provide students with the ability to do the following:

1. Become familiar with test equipment

2. Plan and design experiments

3. Develop and implement experimental procedures

4. Implement measurement and data collection techniques

5. Use modeling procedures to validate existing or expected results

6. Document experimental work

7. Report findings in writing or orally

\section{Evaluation of ET Program}

The ET program will be using the SME certification exam as one of the several assessment valuation tool to evaluate the program. In addition, the level of students competency and performance in the capstone course can also be used as part of the overall evaluation of the program. 


\section{Role of Industry}

The support of local industry is essential for the success of mechanical and electrical engineering technology programs. Local industry can be tapped for financial support and it is a great source of generating topics for research. Industry can provide students with real-world problems to solve in the classroom environment. An industry and a university can work together on projects that benefit each other. Personal exchange with industry is another way of enriching the curriculum. ${ }^{6}$

\section{Conclusions}

The manufacturing environment requirements and needs are different than those used a decade ago. The engineering technology education program should reflect the needs and changes of today's industry and prepare young engineer technologist to meet the challenges of the competitive world of manufacturing. There is a need for highly trained engineering technologist who have the knowledge and skills to work in this environment. Industry needs engineer technologist-who have the understanding of basic manufacturing theory and the ability to apply knowledge that is relevant to the real world of manufacturing.

Dr. Bob Lahidji is a assistant professor in the Industrial Technology Program at Eastern Michigan University. His primary interest and expertise are in the area of manufacturing process and CNC/CAM. Dr. Lahidji has been involved with manufacturing firms as a consultant in the area of improving manufacturing processes.

\section{References}

1. Engineering Technology Council. (1991). Educational issues of importance to the engineering technology council (ETC) of the ASEE. Unpublished manuscript.

2. American Society for Engineering Education. (1994). Directory of Engineering and Engineering Technology Undergraduate Programs. Washington DC: Author.

3. Israel, E. N. (1995). Technology education and other technically related programs. Foundations of technology education. In G.E. Martin (Ed.), 44th Yearbook. New York: Glencoe, McGraw-Hill.

4. Speelman, P \& Lahidji, B. (I 996). Reasons for adding to or changing from Industrial Technology (IT) to

Engineering Technology (ET). National Association of Industrial Technology. Manuscript submitted for publication.

5. Accreditation Bard for Engineering Technology (1992). Criteria for accrediting programs in engineering technology. New York- Author.

6. Barez, F. (1990). Development of a manufacturing engineering program at the undergraduate. American Society for Engineering Education: Proceeding of the 1990 annual meeting and conference of the American Society for Engineering Education Pacific Southwest $\underline{\text { Section. }}$ 